\title{
Analisis profesi hakim dalam epistemologi hukum Islam
}

\author{
Sakirman \\ Fakultas Syariah LAIN Metro Lampung \\ E-mail:sakirman87@gmail.com \\ DOI: 10.18326/ijtihad.v17i1.135-154
}

Ethics is the foundation of a profession which becomes a common concern because of frequent misuse symptoms to the profession. The emergence of the discourse of professional code of ethics for judges departed from the reality of law enforcement officials (especially judges) that ignores the values of morality. Although professional actors (judges) already have the code of professional conduct of judges as moral standards, it has not been a positive impact, especially not able to change the image of society to face justice for the better. Existing code of ethics is not providing value in favor of the realization of the purpose of the law, so it needs to be reviewed or revised to suit the changing situation. One way to enforce the rule of law is to enforce ethics, professionalism, and discipline. The values contained in the code of professional conduct of judges in an ethical standpoint of Islamic law is very important to be studied. Professional ethics of judges in principle contain moral values underlying professional personality, namely freedom, fairness and honesty. Professional ethics of judges and law is a unity that is inherently contained ethical values of Islam which is the foundation of understanding the Islamic law, so basically the code of professional conduct of judges in line with the values of the Islamic ethical system. Islamic legal ethics built on four basic values which are the values of truth, justice, free will and responsibility.

Etika merupakan landasan suatu profesi sehingga menjadi perhatian bersama karena sering terjadi gejala-gejala penyalahgunaan terhadap profesi. Munculnya wacana pemikiran tentang kode etik profesi hakim karena berangkat dari realitas para penegak hukum (khususnya hakim) yang mengabaikan nilainilai moralitas. Meskipun para pelaku professional (hakim) sudah memilki kode etik profesi hakim sebagai standar moral, ternyata belum memberikan dampak yang positif, terutama belum bisa merubah image masyarakat terhadap wajah peradilan untuk menjadi lebih baik. Kode etik yang sudah ada belum memberikan nilai yang berpihak kepada terwujudnya tujuan hukum, sehingga perlu dikaji kembali atau direvisi untuk disesuaikan dengan perubahan situasi. Salah satu jalan untuk menegakkan supremasi hukum adalah dengan cara menegakkan etika, profesionalisme, dan disiplin. Nilai-nilai yang terkandung dalam kode etik profesi hakim dalam sudut pandang etika hukum Islam sangat penting untuk dikaji. 
ljtihad, Jurnal Wacana Hukum Islam dan Kemanusiaan, Volume 17, No. 1, Juni 2017: 137-154

Kode etik profesi hakim pada prinsipnya mengandung nilai-nilai moral yang mendasari kepribadian secara professional, yaitu kebebasan, keadilan dan kejujuran. Etika profesi hakim dan hukum adalah merupakan satu kesatuan yang secara inheren terdapat nilai-nilai etika Islam yang landasannya merupakan pemahaman dari hukum Islam, sehingga pada dasarnya kode etik profesi hakim sejalan dengan nilainilai dalam sistem etika Islam. Etika hukum Islam dibangun di atas empat nilai dasar yaitu yaitu nilainilai kebenaran, keadilan, kehendak bebas dan pertanggung jawaban.

Keywords: Ethics; Profession; Justice; Islamic Law.

\section{Pendahuluan}

Perkembangan profesi hakim mengimplikasikan kepada tuntutan-tuntutan norma etik yang melandasi persoalan profesional. Namun hal tersebut tidak bisa sempurna karena sifat profesi yang terbatas, khusus dan unggul, maka bukan tidak mungkin akan terjadi gejala-gejala penyalahgunaan terhadap profesi sebagai hakim, yang seharusnya dengan penguasaan dan penerapan disiplin ilmu hukum dapat diemban untuk menyelenggarakan dan menegakkan keadilan di masyarakat.

Hakim sebagai salah satu aparat penegak hukum (legal aparatus) yang sudah memiliki kode etik sebagai standar moral atau kaedah seperangkat hukum formal. Namun realitanya para kalangan profesi hukum belum menghayati dan melaksanakan kode etik profesi dalam melaksanakan profesinya sehari-hari, terlihat dengan banyaknya yang mengabaikan kode etik profesi, sehingga profesi ini tidak lepas mendapat penilaian negatif dari masyarakat.

Berbagai kasus gugatan publik terhadap profesi hakim merupakan bukti bahwa adanya penurunan kualitas hakim sangat wajar sehingga pergeseran pun terjadi dan sampai muncul istilah mafia peradilan. Indikasi tersebut menunjukan hal yang serius dalam penegakkan standar profesi hukum di Indonesia. Kode etik tampaknya belum bisa dilaksanakan dan nilai-nilai yang terkandung belum bisa diaplikasikan oleh pengembannya sendiri.

Islam menjelaskan bahwa hakim adalah seorang yang diberi amanah untuk menegakkan keadilan dengan nama Tuhan atas sumpah yang telah diucapkan, dalam pandangan Islam adalah kalimat tauhid adalah amalan yang harus diwujudkan dalam bentuk satu kata dan satu perbuatan dengan niat lillahi ta'alla. Sehingga pada setiap putusannya benar-benar mengandung keadilan dan kebenaran. 
Munculnya wacana pemikiran tentang kode etik profesi hakim ini akan menjadi bahan masukan bagi penegak sebagai bahan evaluasi yang menitik beratkan pada analisis nilai-nilai Islam yang terkandung dalam kode etik profesi hakim. Kajian ini penting karena didorong oleh realitas profesi hakim yang mengabaikan nilai-nilai moralitas. Dan untuk membangun kembali kepercayaan publik terhadap lembaga peradilan sebagai benteng terakhir keadilan khususnya hakim.

\section{Konsep hakim dalam dialektika wacana}

Hakim berasal dari kata حكى - semakna dengan qadhi yang berasal dari kata artinya memutus. Sedangkan menurut bahasa adalah orang yang bijaksana atau orang yang memutuskan perkara dan menetapkannya (Madkur, tt: 11). Adapun pengertian menurut syar'a yaitu orang yang diangkat oleh kepala negara untuk menjadi hakim dalam menyelesaikan gugatan, perselisihan-perselisihan dalam bidang hukum perdata oleh karena penguasa sendiri tidak dapat menyelesaikan tugas peradilan (Shidieqi,1997:39) sebagaimana pernah di peraktekan oleh nabi Muhammad ketika mengangkat qodi untuk bertugas menyelesaikan sengketa di antara manusia di tempat-tempat yang jauh, sebagaimana ia telah melimpahkan wewenang ini pada sahabatnya. Hal ini terjadi pada sahabat dan terus berlanjut pada Bani Umayah dan Bani Abbasiah, diakibatkan dari semakin luasnya wilayah Islam dan kompleknya masalah yang terjadi pada masyarakat, sehingga diperlukan hakim-hakim untuk menyelesaikan perkara yang terjadi.

Hakim adalah pejabat peradilan negara yang diberi wewenang oleh undang-undang untuk mengadili. Sedangkan dalam Undang-undang kekuasaan kehakiman adalah penegak hukum dan keadilan wajib menggali, mengikuti dan memahami nilai-nilai hukum yang hidup di masyarakat. Ketentuan ini dimaksudkan agar putusan hakim sesuai dengan hukum dan rasa keadilan masyarakat. lihat Undang-undang Nomor 4 Tahun 2004 Tentang Kekuasaan Kehakiman beserta penjelasannya, Pasal 28 Ayat (1). Dengan demikian hakim adalah sebagai pejabat Negara yang diangkat oleh kepala Negara sebagai penegak hukum dan keadilan yang diharapkan dapat menyelesaikan permasalahan yang telah diembannya menurut Undangundang yang berlaku. 
ljtihad, Jurnal Wacana Hukum Islam dan Kemanusiaan, Volume 17, №. 1, Juni 2017: 137-154

Hakim sebagai pelaksana hukum mempunyai kedudukan yang sangat penting sekaligus mempunyai beban yang sangat berat. Dipandang penting karena melalui hakim akan tercipta produk-produk hukum baik melalui ijtihad yang sangat dianjurkan sebagai keahlian hakim yang diharapkan dengan produk tersebut segala bentuk kedhaliman yang terjadi dapat tercegah dan diminimalisir sehingga ketentraman masyarakat terjamin. Dari tugas hakim ini menunjukkan posisi hakim sangat penting sebagai unsur badan peradilan. Hakim sebagai salah satu unsur peradilan yang dipandang penting dalam menyelesaikan perkara yang diperselisihkan antara sesama, oleh sebab itu harus didukung oleh pengetahuan dan kemampuan yang professional dengan syarat-syarat yang umum dan khusus yang di tentukan oleh Mahkamah Agung.

Imam Mawardi menambahkan bahwa hakim harus diketahui identitasnya, harus memahami tugas atas pekerjaanya, menyebut wewenangnya dan wilayah meliputi negara atau propinsi (Mawardi, 2000: 142-143). Sedangkan dalam literatur Islam atau fiqih ada beberapa persyaratan yang menjadi persamaan dan perbedaan, persamaannya hakim harus berakal, Islam, adil, berpengetahuan baik dalam pokok hukum agama dan cabang-cabangnya, sehat pendengaran, penglihatan dan ucapan dan merdeka bukan hamba sahaya (Rasjid,1994: 487). Adapun perbedaannya adalah pada fiqih Islam disyaratkan hakim laki-laki dan tidak boleh perempuan yang terjadi khilafiyah diantara para ulama dari empat maz $\backslash$ hab kecuali Abu Hanifah membolehkan selain dalam urusan hadd dan qis $\}$ as $\}$, karena kesaksian dalam dua hal tersebut tidak dapat diterima (Harahap,1993: 35-43). Sedangkan dalam Hadis disebutkan :

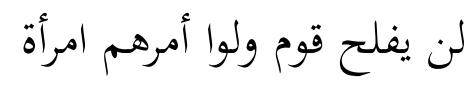

Hadis di atas menerangkan bahwa perempuan dianggap belum mampu membawa kemenangan atau kemajuan. Ini merupakan pendapat lama karena melihat kondisi perempuan yang berbeda dengan masa sekarang, sehingga sekarang ini wanita boleh menjadi hakim asalkan mempunyai keahlian serta memenuhi persyaratan yang telah ditetapkan oleh hukum positif dan hukum Islam.

Persyaratan-persyaratan tersebut merupakan persyaratan pada masa dahulu dikarenakan luasnya wilayah Islam dan banyaknya permasalahan yang muncul sehingga menjadi komplek 
sedangkan lembaga peradilan masih sangat sedikit, namun dalam kontek sekarang peradilan yang yang sudah merata dan laju kehidupan yang semakin maju sehingga persyaratanpersyaratan itu menjadi dikontekkan secara umum untuk lebih mewadahi pluralitas yang ada, kecuali dalam peradilan agama yang memakai azas personalitas keIslaman sebagai lembaga peradilan khuhus dari lembaga peradilan yang lainnya. Dalam hadiṣ yang dilansir oleh Imām Abì Husain Muslim Bin al-Hajjaj Ibn Muslim al-Qusyairi Annisaburi, Kitab al-

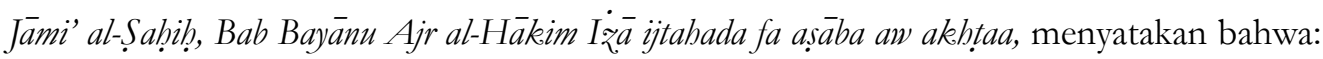

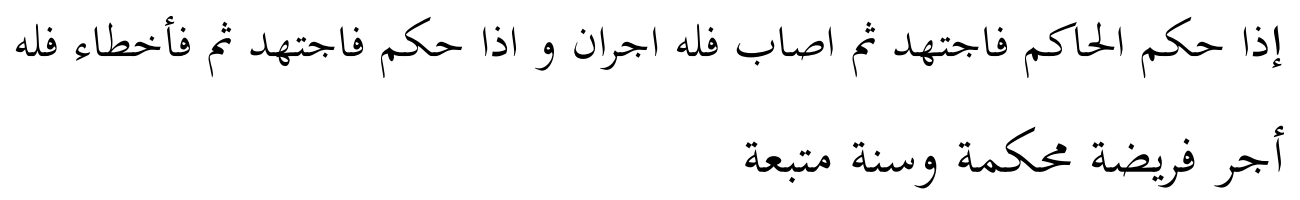

Dari hadis dan ijma' tersebut dijelaskan tentang keutamaan ijtihad, kemuliaan ijtihad yang dilakukan dengan sungguh-sungguh baik benar atau salah akan mendapat pahala. Maksudnya seorang hakim dalam memutuskan perkara yang dihadapinya itu melalui qiyas yang mengacu kepada al-Kitab dan al-Sunah bukan berdasarkan pendapat pribadi, yang terlepas dari keduanya.

Hal ini sebagai salah satu usaha menggali hukum guna melindungi kepentingankepentingan orang-orang yang teraniaya dan untuk mernghilangkan sengketa-sengketa yang timbul dalam masyarakat, akibat dari luasnya wilayah Islam, seperti pada masa bani umayah khalifah hanya mengangkat qad $\}$ i pusat dan di daerah diserahkan pada penguasa daerah dan hanya diberi wewenang untuk memutuskan perkara, sedangkan untuk pelaksanaan putusan oleh khalifah langsung atau oleh utusannya (Madkur, tt: 29). Sedangkan pada masa Bani Abbasiah dibentuknya Mahkamah Agung, pembentukan hakim setiap wilayah, pembukuan dan mulainya organisasi peradilan sehingga menempatkan hakim sebagi sosok yang sangat diperlukan dan mempunyai peranan penting.

Dalam menjalankan tugasnya, hakim memiliki kebebasan untuk membuat keputusan terlepas dari pengaruh pemerintah dan pengaruh lainnya (Bisri,1997: 104). Hakim menjadi tumpuan dan harapan bagi pencari keadilan. Disamping itu mempunyai kewajiban ganda, disatu pihak merupakan pejabat yang ditugasi menerapkan hukum (ižhar al-hukm) terhadap perkara yang konkrit baik terhadap hukum tertulis maupun tidak tertulis, dilain pihak sebagai 
ljtihad, Jurnal Wacana Hukum Islam dan Kemanusiaan, Volume 17, №. 1, Juni 2017: 137-154

penegak hukum dan keadilan dituntut untuk dapat menggali, memahami, nilai-nilai yang ada dalam masyarakat. Secara makro dituntut untuk memahami rasa hukum yang hidup di dalam masyarakat.

Dalam undang-undang disebutkan tugas pengadilan tidak boleh menolak untuk memeriksa, mengadili dan memutus suatu perkara yang diajukan dengan dalih bahwa hukum tidak ada atau kurang jelas, melainkan wajib untuk memeriksa dan mengadilinya. Artinya hakim sebagai unsur pengadilan wajib menggali, mengikuti dan memahami nilai-nilai hukum dan rasa keadilan yang hidup dalam masyarakat. Nilai-nilai hukum yang hidup dalam masyarakat tersebut seperti persepsi masyarakat tentang tentang keadilan, kepastian, hukum dan kemamfaatan. Hal ini menjadi tuntutan bagi hakim untuk selalu meningkatkan kualitasnya sehingga dalam memutuskan perkara benar-benar berdasarkan hukum yang ada dan keputusannya dapat dipertanggungjawabkan, seperti halnya yang diungkapkan (al-Asqalani, tt.: 316) dalam hadis berikut:

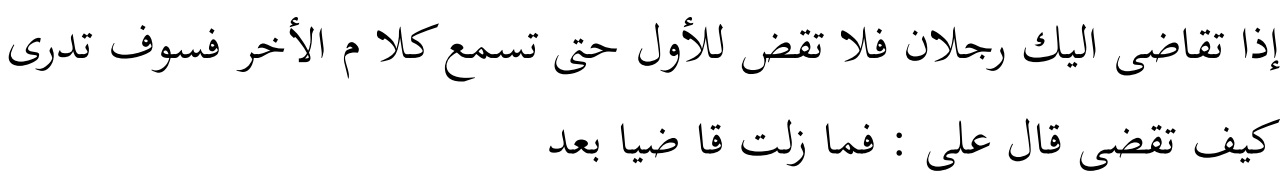

Dalam menyelesaikan suatu perkara ada beberapa tahapan yang harus di lakukan oleh hakim diantaranya seperti yang diungkapkan Arto (2000: 37) adalah mengkonstatir yaitu yang dituangkan dalam Berita Acara Persidangan dan dalam duduknya perkara pada putusan hakim. Mengkonstatir ini dilakukan dengan terlebih dahulu melihat pokok perkara dan kemudian mengakui atau membenarkan atas peristiwa yang diajukan, tetapi sebelumnya telah diadakan pembuktian terlebih dahulu, mengkualifisir yaitu yang dituangkan dalam pertimbangan hukum dalam surat putusan. Ini merupakan suatu penilaian terhadap peristiwa atas bukti-bukti, fakta-fakta peristiwa atau fakta hukum dan menemukan hukumnya, dan mengkonstituir yaitu yang dituangkan dalam surat putusan. Tahap tiga ini merupakan penetapan hukum atau merupakan pemberian konstitusi terhadap perkara.

Tahapan-tahapan tersebut menjadikan hakim dituntut untuk jeli dan hati-hati untuk memberikan keputusan sekaligus menemukan hukumnya, karena pada dasarnya hakim dianggap mengetahui hukum dan dapat mengambil keputusan berdasarkan ilmu pengetahuan 
dan keyakinannya sesuai dengan doktrin Curia Ius Novit (Muhammad, 1992: 37). Karena dalam undang-undang dijelaskan bahwa hakim tidak boleh menolak perkara yang diajukan kepadanya untuk diperiksa dan diputus, dengan alasan bahwa hukum yang ada tidak ada atau kurang jelas.

Sedangkan fungsi hakim adalah menegakkan kebenaran sesungguhnya dari apa yang dikemukakan dan dituntut oleh para pihak tanpa melebihi atau menguranginya terutama yang berkaitan dengan perkara perdata, sedangkan dalam perkara pidana mencari kebenaran sesungguhnya secara mutlak tidak terbatas pada apa yang telah dilakukan oleh terdakwa, melainkan dari itu harus diselidiki dari latar belakang perbuatan terdakwa (Muhammad, 1992: 38). Artinya hakim mengejar kebenaran materil secara mutlak dan tuntas.

Dengan demikian tugas hakim adalah melaksanakan semua tugas yang menjadi tanggung jawabnya untuk memberikan kepastian hukum semua perkara yang masuk baik perkara tersebut telah di atur dalam Undang-undang maupun yang tidak terdapat ketentuannya. Disini terlihat dalam menjalankan tanggung jawabnya hakim harus bersifat obyektif, karena merupakan fungsionaris yang ditunjuk undang-undang untuk memeriksa dan mengadili perkara, dengan penilaian yang obyektif pula karena harus berdiri di atas kedua belah pihak yang berperkara dan tidak boleh memihak salah satu pihak.

\section{Kode etik hakim : menuju hakim profesional}

Pemahaman terhadap eksistensi kode etik profesi hakim dalam wacana pemikiran hukum Islam adalah sistem etika Islam yang akan menjadi landasan berfikir untuk melihat nilai-nilai yang ada dalam kode etik profesi hakim. Etika dalam Islam disebut dengan akhlak. Akhlak berasal dari bahasa arab yang artinya perangai, tabiat, rasa malu dan adat kebiasaan atau dalam pengertian sehari-hari disebut budi pekerti, kesusilaan atau sopan santun. Dengan demikian ahklak merupakan gambaran bentuk lahir manusia (Nasir, 1991: 14).

Ahmad Amin memberikan definsi akhlak adalah suatu ilmu yang menjelaskan arti baik dan buruk, menerangkan apa yang harusnya dilakukan oleh sebagian manusia kepada manusia lainnya, menyatakan apa yang harus dituju oleh manusia dalam hal perbuatan mereka dan menunjukkan jalan apa yang harus diperbuat (Amin, 1995: 3).

Sedangkan menurut A. Mustofa akhlak dalam Islam (akhlak Islam) adalah merupakan sistem moral atau akhlak yang berdasarkan Islam, yakni bertitik tolak dari akidah yang 
ljtihad, Jurnal Wacana Hukum Islam dan Kemanusiaan, Volume 17, №. 1, Juni 2017: 137-154

diwahyukan Allah pada Nabi atau Rasul-Nya yang kemudian disampaikan pada umatnya (Mustofa, 1997: 149). Akidah tersebut diwujudkan menjadi tabiat atau sifat seseorang, yakni telah biasanya dalam jiwa seseorang yang benar-benar telah melekat sifat-sifat yang melahirkan perbuatan-perbuatan dengan mudah dan spontan tanpa dipikirkan. Perbuatan tersebut terkadang berbentuk baik dan terkadang juga berbentuk buruk.

Dengan demikian pada tahap pertama merupakan hasil pemikiran atau pertimbangan tetapi lama-lama menjadi melekat dan tanpa pertimbangan dan pemikiran. Dan dapat dikatakan akhlak merupakan manifestasi iman, Islam dan ihsan yang merupakan repleksi sifat dan jiwa secara spontan yang terpola pada diri sendiri sendiri sehingga dapat melahirkan perilaku secara konsisten dan tidak tergantung pada pertimbangan interes tertentu (Sidiktono, 1998: 89).

Majid Fakhry menyebutkan etika atau akhlak adalah gambaran rasional mengenai hakikat dan menjadi dasar perbuatan dan keputusan yang benar serta prinsip-prinsip yang menentukan klaim bahwa perbuatan dan keputusan tersebut secara moral diperintahkan atau dilarang (Fakhry, 1996: xv-xvi). Lebih ditegaskan lagi etika adalah merupakan hal keyakinan religius tertentu (I'tiqäăat) untuk diamalkan, dan bukan demi pengetahuan belaka (Quasem, 1988: 10). Dari pengertian di atas etika dan akhlak kalau dipahami adalah merupakan dua kata yang mempunyai kesamaan dan juga perbedaan, persamaanya adalah pada obyek yakni sama-sama membahas tentang baik dan buruk tingkah laku manusia sedangkan perbedaanya adalah pada parameternya yaitu etika terhadap akal, dan akhlak terhadap agama.

Dengan demikian etika mempunyai peranan penting karena lebih menekankan pada bentuk bathiniyah yang berkaitan dengan pelaksanaan hukum (syari'ah) yang berbentuk batiniyah. Lebih jauh lagi merupakan aspek penting bagi penegak hukum, khususnya profesi hakim. Karena moralitas atau etika sebagai dorongan terhadap keadaan jiwa yang diwujudkan dalam melaksanakan profesinya.

Persoalan etika dalam Islam sudah banyak dibicarakan dan termuat dalam al-Qur'an dan al-Hadis. Etika Islam adalah merupakan sistem akhlak yang berdasarkan kepercayaan kepada tuhan, dan sudah tentu berdasarkan kepada agama, dengan demikian al-Qur'an dan al-Hadis adalah merupakan sumber utama yang dijadikan landasan dalam menentukan batasanbatasan dalam tindakan sehari-hari bagi manusia, ada yang menerangkan tentang baik dan buruk, boleh dan dilarang, maka etika profesi hakim di sini merupakan bagian dari perbuatan 
yang menjadi fokus bahasan.

Namun al-Qur'an yang menerangkan tentang kehidupan moral, keagamaan dan sosial muslim tidak menjelaskan teori-teori etika dalam arti yang khusus sekalipun menjelaskan konsep etika Islam, tetapi hanya membentuk dasar etika Islam, bukan teori-teori etika dalam bentuk baku (Fakhry, 1996: xv). Tetapi masalah yang paling utama adalah bagaimana mengeluarkan ethik Islam yang bersumber dari al-Qur'an yang melibatkan seluruh moral, keagamaan, dan sosial masyarakat muslim guna menjawab semua permasalahan yang timbul baik dari dalam maupun dari luar.

Dari kedua sumber tersebut yang pada umumnya memiliki sifat yang umum, karena itu perlu dilakukan upaya-upaya dan kualifikasi agar dipahami sehingga perlu melalui penjelasan dan penafsiran. Permasalahan kehidupan manusia yang semakin kompleks dengan dinamika masyarakat yang semakin berkembang. Maka akan dijumpai berbagai macam persoalan terutama masalah moralitas masyarakat muslim, pada masa Nabi Muhammad yang terbentuk setelah turunnya wahyu al-Qur'an, sehingga masih bisa dikembalikan kepada sumber alQur'an dan penjelasan dari Nabi sendiri. Seiring dengan perkembangan masyarakat dan keagamaan ketika itu yang dihadapkan dengan masalah budaya, adat dan pola pikir masyarakat yang berkembang saat itu, maka keadaan moralitas menjadi sangat penting dan komplek.

Al-Qur'an sendiri menjelaskan tentang etika dengan berdasarkan tiga terma kunci, utama yang merupakan pandangan dunia al-Qur'an. Ketiga terma kunci tersebut adalah iman, Islam, dan taqwa yang jika direnungkan akan memperlihatkan arti yang identik. Istilah iman berasal dari akar kata (أمن) yang artinya "keamanan”, "bebas dari bahaya, "damai", Islam yang akar katanya (سلم) yang artinya "aman dan integral", "terlindungi dari disintegrasi dan kehancuran". Dan taqwa yang sangat mendasar bagi al-Qur'an disamping kedua istilah di atas, yang memiliki akar kata (وقي) juga berarti "melindungi dari bahaya", "menjaga kemusnahan, kesia-siaan, atau disintegrasi” (Rahman, 1992: 66). Sehingga pembahasan etika yang terdapat dalam al-Qur'an mengandung cakrawala yang luas karena menyangkut nilainilai yang terkandung dalam kehidupan manusia baik secara individu, masyarakat dan Negara secara umum demi mencapai kebahagian baik di dunia dan di akhirat.

Menurut Madjid Fakhri sistem etika Islam dapat dikelompokkan menjadi empat tipe. Pertama, moral skripturalis. Kedua, etika teleologis. Ketiga, teori-teori etika filsafat. Keempat, 
ljtihad, Jurnal Wacana Hukum Islam dan Kemanusiaan, Volume 17, №. 1, Juni 2017: 137-154

etika religius. Dari keempat tipologi etika Islam tersebut, etika religius akan menjadi pilihan sebagai landasan teori yaitu nilai-nilai etika yang didasarkan pada konsep al-Qur'an tentang nilai-nilai etika hukum dalam Islam. Dengan demikian penyusun hanya akan menjelaskan salah satu macam etika yaitu etika religius yang menjadi landasan.

Etika religius adalah etika yang dikembangkan dari akar konsepsi-konsepsi al-Qur'an tentang manusia dan kedudukannya di muka bumi, dan cenderung melepaskan dari kepelikan dialektika dan memusatkan pada usaha untuk mengeluarkan spirit moralitas Islam secara utuh. Bahan-bahan etika religius adalah pandangan-pandangan dunia al-Qur'an, konsepkonsep teologis, kategori-kategori filsafat dan dalam beberapa hal sufisme. Karena itu sistem etika religius muncul dalam berbagai bentuk yang kompleks sekaligus memiliki karakteristik yang paling Islami. Diantara eksponennya adalah Hasan al-Basri, al-Mawardi, al-Ragib alIsfahani, al-Gazali, dan Fakhruddin ar-Razi. al-Gazali yang sistem etikanya mencakup moralitas filosofis, teologis, dan sufi, adalah contoh yang paling representatif dari etika religius.

Sementara kajian epistemologi terhadap nilai-nilai suatu perbuatan, oleh F. Huorani dikelompokkan menjadi empat aliran, yaitu: Pertama, Obyektifisme; "right" memiliki arti yang obyektif, yaitu suatu perbuatan itu disebut benar apabila terdapat kualitas benar pada perbuatan itu. Aliran ini biasanya dimiliki oleh aliran mu'tazilah dan filsuf muslim. Kedua, Subyektivism; "right" tidak memiliki arti yang obyektif, tetapi sesuai dengan kehendak dan perintah dan ketetapan Allah swt. Tipe ini disebut secara spesifik oleh George F. Huorani dengan theistic subjectivisme atau divine subjectivisme. Terma ini disepadankan oleh George F. Huorani dengan sebutan ethical voluntarism. Ketiga, Rationalism; 'right" itu dapat diketahui dengan akal semata atau akal bebas. Artinya, akal manusia dinilai mampu membuat keputusan etika yang benar berdasarkan data pengalaman tanpa menunjuk kepada wahyu. Aliran ini dengan pendayaannya terhadap akal disepadankan oleh George F. Huorani dengan kelompok intuitionist. Aliran ini terbagi menjadi dua yaitu: pertama, "right" selalu dapat diketahui oleh akal secara bebas. Kedua, "right" dalam beberapa kasus dapat diketahui oleh akal semata, pada kasus lain diketahui oleh wahyu, sunnah, ijmâ', dan qiyâs, atau dapat diketahui oleh akal dan wahyu dan seterusnya. Aliran ini secara spesifik disebut dengan partial rationalism. Keempat,Traditionalism; "right" tidak akan pernah dapat diketahui dengan akal semata tetapi hanya dapat diketahui dengan wahyu dan sumber-sumber lain yang merujuk kepada wahyu. 
Menurut George F. Huorani, aliran ini bukan tidak sama sekali tidak memanfaatkan kemampuan akal, tetapi kemampuan akal dipergunakan pada saat menafsirkan al-Qur'ân dan sunnah, menetapkan ijma'atau menarik qiyas. Aliran seperti ini biasanya dianut oleh para fuqoha dan mutakallimun (Amril, 2001: 25-27).

Kata profesi dalam al-Qur'ân disebutkan dengan kata-kata 'aml (عمل) yang disebut berulang-ulang, belum lagi dengan penyebutan yang lain atau kiasan lain. Namun ada sebagian orang yang menyebutkan bahwa Islam tidak progresif terhadap budaya kerja. Hal ini karena disebabkan didalam Islam adanya takdir, yang sering dipahami secara negatif atas pemahaman bahwa dalam Islam tidak terlalu penting. Ini bias dari teologi jabariyah (aliran aqidah yang berpendapat bahwa manusia tidak punya faktor atau penentu). Sehingga faktor adanya kemiskinan akibat dari faktor dari teologis ini (Tono, 1998: 133-134).

\section{Etika Islam dalam penegakan hukum}

Sistem etika Islam yang berkembang terlebih dahulu dalam pemahaman agama, sehingga hubungan antara agama dengan etika mempunyai relasi yang erat. Keduanya memang tidak dapat dipisahkan. Keterbatasan kemampuan manusia untuk mamahami ajaran agama menyebabkan perlunya manusia mencari jalan dan berfikir yang tepat untuk membantu manusia dalam menafsirkan agama, karena tidak semua orang sepakat dalam suatu pendapat. Begitu juga terhadap peristiwa-peristiwa sekarang yang dulunya masih belum menjadi persoalan agama dapat dipecahkan melalui etika dengan memperhatikan ketentuan agama.

Agama biasanya dipahami semata-mata membicarakan urusan spiritual, karenanya ada ketegangan antara agama dan hukum. Hukum utuk memenuhi kebutuhan sosial dan karenanya mengabdi kepada masyarakat untuk mengontrolnya dan tidak membiarkannya menyimpang dari kaedahnya, yaitu norma-norma yang ditentukan oleh agama (Muslehuddin, 1997: 70). Agama di sini menekankan moralitas, perbedaan antara yang benar dan salah, baik dan buruk, sedangkan hukum duniawi memfokuskan diri kepada kesejahteraan material dan kurang memperhatikan etika. Terlihat dengan adanya perbedaan antara fungsi antara etika dengan ilmu hukum yaitu etika dalam agama memerintahkan berbuat apa yang berguna dan melarang segala perbuatan yang dilarang dan madarat sedangkan ilmu hukum tidak karena banyak perbuatan yang baik dan berguna yang tidak diperintahkan oleh ilmu hukum. 
ljtihad, Jurnal Wacana Hukum Islam dan Kemanusiaan, Volume 17, №. 1, Juni 2017: 137-154

Dari fungsi di atas menjadikan etika atau akhlak mendalami gerak jiwa manusia secara batin walaupun tidak menimbulkan perbuatan lahir sedangkan ilmu hukum melihat segala perbuatan yang berakibat kepada lahir. Hukum Islam sebenarnya merupakan hukum moral "farexcellence", sedangkan menurut Khan : "bukum moral adalab bukum dalam arti sebenarnya.Tidak adapemisahan total bukum dari moralitas". Oleh karena itu hukum yang dipisahkan dari keadilan dan moralitas bukanlah hukum.

Dengan demikian etika sangat bermanfaat bagi seorang walaupun pada dasarnya manusia itu sudah bermoral. Manfaat etika itu antara lain agar manusia dapat mengadakan refleksi kritis dalam menghadapi masyarakat yang semakin pluralistik dimana kesatuan normatif sudah tidak ada lagi. Perubahan-perubahan masyarakat karena arus modernisasi mengakibatkan goncangan nilai budaya yang bisa saja berubah dan mana nilai yang tetap dan tidak mungkin berubah. Etika dapat juga membuat kita sanggup menghadapi ideologi yang menawarkan darinya sebagai penyelamat dengan memecahkanya secara kritis dan obyektif (Suseno, 1990: 15-16).

Etika Islam sebagai landasan yang harus dijunjung oleh seorang profesi dalam hal ini seorang hakim (Qadi) dalam menjalankan profesinya adalah memberi keputusan (Judgement) bukan menghadiahkan keadilan dan keputusan yang diberikan harus berdasarkan hukum. Hal ini dalam konsep Islam, profesi hakim harus benar-benar menegakkan etika, dan bagaimana etika yang harus ditegakkan dalam menjalani profesi dalam Islam, atau yang disebut etika profesi dalam Islam.

Konsep profesi dalam Islam adalah pertama, meletakkan kerja sebagai sebuah amal shaleh yang dilakukan dalam kontek dan tahapan yang runtut atas iman, ilmu, dan amal. Disini kerja terorientasi kepada dua pandangan : aktifitas yang bernilai ibadah dan sebuah aktifitas untuk memperoleh keuntungan financial. Kedua, menunuaikan kerja sebagai suatu penunaian amanah yang harus dilakukan secara professional. Ketiga, melakukan kerja dengan wawasan masa depan dan wawasan ukhrawi artinya dalam melakukan kerja, seseorang harus mengingat kepentingan akan hari depannya (Sidiktono, tt: 138).

Dari uraian di atas etika profesi dalam Islam adalah merupakan aktivitas yang bukan hanya bersifat duniawi, melainkan juga sangat ukhrawi. Artinya Islam melibatkan aspek transendental dalam beribadah, sehingga bekerja tidak hanya bisa dilihat sebagai prilaku 
ekonomi tetapi juga ibadah, sehingga profesi hakim yang dijalani adalah suatu profesi yang profesi yang harus dipertanggung jawabkan di akhirat. Dalam hadis (al-Asqalani, tt: 315) disebutkan:

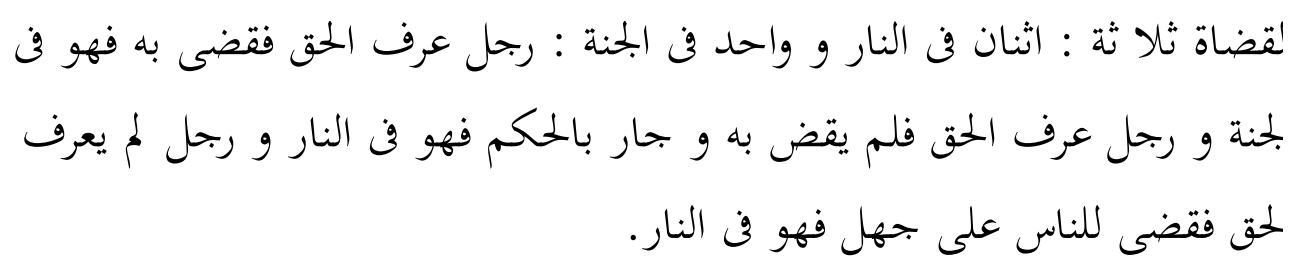

Hadis diatas menjelaskan pembagian hakim, sehingga apabila haim tidak menjalankan amanahnya sesuai dengan sistem etika profesi dalam Islam maka termasuk salah satu golongan hakim yang celaka, karena mengimgkari tujuan dari etika profesi hakim yang ada, dan tidak bisa mempertanggungjawabkan akan tugasnya diakhirat nanti.

Hal ini diungkapkan oleh al-Gazali, bahwa tujuan etika dalam Islam berpangkal dari pengabdian sepenuhnya pada Tuhan. Pemikiran etika al-Ghazali sangat menekankan pada keselamatan individu baik di dunia sekarang maupun di akhirat nanti. Adanya kewajiban bagi manusia pada hakekatnya dimaksudkan untuk keselamatan individu (Abdullah, 2002: 202-205).

Setelah dijelaskan landasan dan hubungan etika agama dalam penegakkan hukum, selanjutnya akan dipaparkan suatu konsep dari suatu paradigma etika profesi yang dikontruksi dari nilai-nilai atau prinsip-prinsip etika profesi hakim dari lintasan sejarah secara normatif. Seperti dikatakan A. Hanafi, sistem etika Islam selalu tercermin dalam konsep tauhid (Hanafi, 1992: 12). Oleh karena itu bagi seorang hakim dalam melaksanakan profesinya harus taat pada prinsip-prinsip peradilan yang telah yang telah digariskan oleh al-Qur'an, sebagai pertimbangan dalam menjalani profesinya, karena ketaatan terhadap prinsip-prinsip akan memberikan jaminan terhadap terlaksananya tujuan hukum. Paradigma etika profesi dalam perspektif al-Qur'an tentang profesi yang dilandasi aksioma-aksioma yang menjadi bahan analisis untuk menkaji kode etik profesi hakim. Aksioma nilai tersebut adalah: Pertama; Keadilan. Keadilan atau keseimbangan (equiblirium) menggambarkan dimensi horizontal ajaran Islam yang berhubungan dengan keseluruhan hubungan antara alam semesta. Sifat keadilan atau keseimbangan bukan hanya karakteristik alami,melainkan merupakan karakteristik dinamis yang harus diperjuangkan oleh setiap muslim dalam kehidupannya (Muhammad, 2002: 12). 
ljtihad, Jurnal Wacana Hukum Islam dan Kemanusiaan, Volume 17, №. 1, Juni 2017: 137-154

Kata keadilan dalam al-Qur'an menggunakan kata 'adldan qist. 'adlmengandung pengertian yang identik dengan samiyyah berarti penyamarataan (equalizing), dan kesamaan (leveling). Penyamarataan dan kesamaan ini berlawanan dengan zulm dan jaur (kejahatan dan penindasan) (Engineer, 2000: 59). Al-Qur'an memiliki banyak keterangan tentang dalil keadilan yang meliputi perintah penegakkan keadilan baik melalui perkataan, tindakan, sikap; baik hati ataupun pikiran, disamping perintah penegakkan keadilan dalam kode etik yang mempunyai unsur nilai, obyek dan tujuan dari keadilan sendiri.

Keadilan yang ditunjukkan hukum Islam adalah keadilan yang mutlak dan sempurna bukan keadilan yang relatif dan parsial. Maka keadilan hukum Islam adalah mencari motif keadilan yang paling dalam, misalnya, perbuatan itu ditentukan oleh niat dan kita berbuat seolah-olah di hadapan Allah (Muslehuddin, 1991: 81). Dalam persfektif Islam dijelaskan keadilan sebagai prinsip yang menunjukan kejujuran, keseimbangan, kesederhanaan dan keterusterangan yang merupakan nilai-nilai moral yang ditekankan dalam al-Qur'ân (A’la, 2000: 159). Karena hukum Islam sendiri mempunyai standar keadilan mutlak karena dilandaskan pada prinsip-prinsip hukum yang fundamental, sehingga keadilan dalam hukum Islam merupakan perpaduan yang menyenangkan antara hukum dan moralitas.

Hukum Islam tidak menghancurkan kebebasan individu tetapi mengontrolnya demi kepentingan masyarakat yang terdiri dari individu itu sendiri dan karenanya juga melindungi kepentingan pribadi dengan kepentingan masyarakat dan bukan sebaliknya. Individu diperbolehkan mengembangkan hak pribadinya dengan syarat tidak mengganggu kepentingan masyarakat, karena manusia hidup berada ditengah perjuangan dalam diri sendiri dan orang lain dalam menegakkan keadilan (Nurdin,1993: 266). Ini mengakhiri perselisihan dan memenuhi tuntutan keadilan karena itu, berlaku adil berarti hidup menurut prinsipprinsip Islam (Azizy, 2003: 122-125).

Kedua; Kebenaran selain mengandung makna kebenaran lawan kesalahan, mengandung juga unsur kebajikan dan kejujuran. Nilai kebenaran adalah merupakan nilai yang dianjurkan dalam ajaran Islam. Dalam al-Qur'an aksioma kebenaran yang mengandung kebajikan dan kejujuran dapat ditegaskan atas keharusan memenuhi perjanjian dalam melaksanakan profesi. Dalam kontek etika profesi hakim yang harus di lakukan adalah dalam hal sikap dan prilaku yang benar yang meliputi dari proses penerimaan perkara, pemeriksaan perkara serta menggali 
nilai-nilai yang ada atau hukum-hukum yang ada untuk menyelesaikan perkara yang masuk sampai kepada pemutusan perkara yang benar-benar sesuai hukum yang berlaku.

Kebajikan adalah sikap ihsan, yang merupakan tindakan yang memberikan keuntungan bagi orang lain. Dalam pandangan Islam sikap ini sangat dianjurkan, sedangkan kejujuran dipandang sebagai suatu nilai yang paling unggul dan harus miliki oleh seluruh masyarakat karena menjadi corak nilai manusia yang berakar (Izutsu, 1993: 148). Dalam al-Qur'an sendiri bukan memperlihatkan tujuan dari kebenaran tetapi memperlihatkan proses. Al-Qur'an menekankan adanya kebenaran suatu profesi yang dilandasi oleh kebaikan dan kejujuran (Muhammad, 2002: 20-21). Al-Qur'an S al-Hajj [22 ]; 77 menjelaskan :

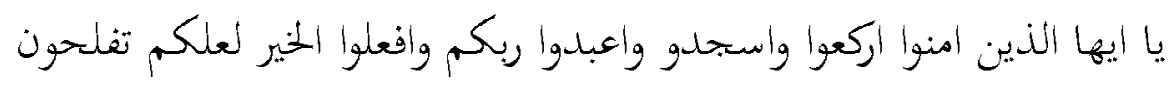

Pengejawantahan aksioma kebenaran dengan dua makna kebajikan dan kejujuran secara jelas telah di teladankan oleh Nabi Muhammad SAW yang juga merupakan seorang yang seiring memutuskan perkara dengan bijaksana. Dalam menjalankan profesinya nabi tidak pernah sekalipun melakukan kebohongan atau berpihak kepada salah satu yang berperkara, namun sebaliknya menganjurkan agar melakukan profesi dengan kebenaran dan kejujuran. Dalam al-Qur'an Surat Ali Imran [3]:114 dinyatakan ;

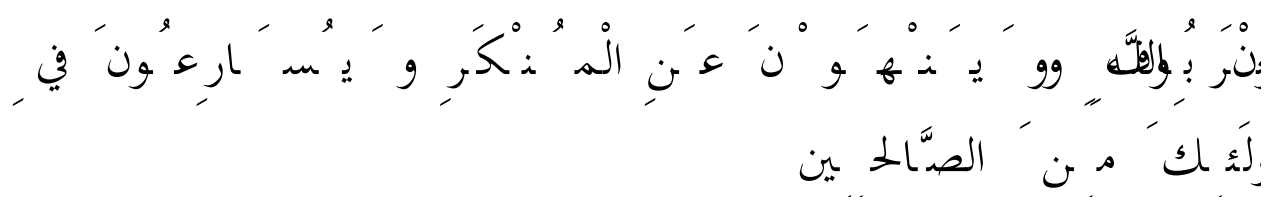

Dengan aksioma-aksioma kebenaran ini maka etika profesi hakim dalam Islam sangat menjaga dan berlaku preventif terhadap kemungkinan adanya penyalahgunaan profesi hakim.

Ketiga; Manusia sebagai khalifah dimuka bumi sampai batas-batas tertentu mempunyai kehendak bebas atau kebebasan untuk mengarahkan kehidupannya kepada tujuan pencapaian kesucian diri. Manusia dianugrahi kehendak bebas atau kebebasan (free Will) untuk membimbing kehidupannya sebagai khalifah (Muhammad, 2002: 15). Berdasarkan aksioma kehendak bebas ini etika profesi dalam Islam mempunyai kehendak bebas dalam menjalani profesinya baik dari perjanjian yang dibuatnya, apakah akan ditepati atau mengingkarinya. Seorang muslim yang percaya terhadap Tuhannya maka ia akan menepati janji atau sumpah dalam melaksanakan profesinya. Dalam al-Qur'an disebutkan : 
ljtihad, Jurnal Wacana Hukum Islam dan Kemanusiaan, Volume 17, №. 1, Juni 2017: 137-154

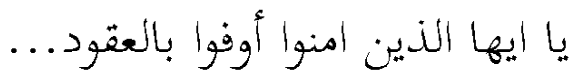

Ayat di atas menjelaskan bahwa kebebasan manusia dalam membuat janji itu harus dipenuhi baik yang dibuat sendiri ataupun dengan masyarakat. Dalam masalah etika profesi yaitu dengan adanya kode etik profesi atau sumpah jabatannya yang harus dilaksanakan. Dengan demikian manusia memiliki kebebasan karena kebebasan adalah kemampuan manusia untuk menentukan dirinya sendiri yang disebut kebebasan eksistensial dari unsur rohani manusia (penguasaan manusia terhadap batinya). Dan kebebasan dari unsur-unsur yang diakibatkan dari orang lain adalah kebebasan sosial.

Namun di satu sisi manusia berada dalam keterpaksaan dan tidak mempunyai kebebasan kehendak yang merdeka bahkan kepastian yang menjalankan menurut apa yang digambarkan. Karena kebebasan adalah merupakan hakikat kemanusiaan, dan kebebasan adalah kebebasan yang ada. Sehingga Herbet Spencer mengatakan " nilai tertinggi yang ia letakkan kepada teori keadilan bukanlah kesamaan tetapi kebebasan " artinya setiap orang bebas asalkan tidak mengganggu orang lain (Muslehuddin, 1991: 36).

Keempat; Kebebasan apapun yang terjadi tanpa batasan, pasti menuntut adanya pertanggungjawaban dan akuntabilitas. Untuk memenuhi keadilan, kebenaran, dan kehendak bebas maka perlu adanya pertanggungjawaban dalam tindakannya. Secara logis aksioma terakhir ini sangat berkaitan erat dengan aksioma kehendak bebas. Ia menetapkan batasan mengenai apa yang bebas dilakukan oleh manusia dengan bertanggungjawab atas semua yang dilakukannya. Tanggung jawab merupakan suatu prinsip dinamis yang berhubungan dengan perilaku manusia. Bahkan merupakan kekuatan dinamis individu untuk mempertahankan kualitas kesetimbangan dalam masyarakat (Fauroni , 2001: 125). Karena manusia yang hidup sebagai mahkluk sosial, tidak bisa bebas, dan semua tindakannya harus dipertanggungjawabkan. Sebagaimana dalam al-Qur'an surat al-Qiyamah (75) ayat: 36 disebutkan :

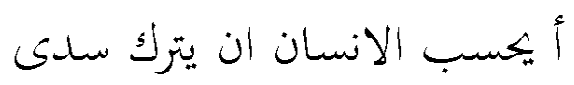

Secara teologis prinsip pertanggungjawaban berhubungan dengan tiga paradigma Qur'anik (Huda, 1996: 119-121). Pertama, Allah memberikan karunia kepada manusia (baik 
melalui Rasul maupun lewat kekuatan akal) yang memungkinkannya mengenali nilai-nilai moral. Dalam jiwa manusia telah ditanamkan pengertian tentang makna baik dan buruk. Sebagaimana dalam al-Qur'an surat an-Nahl (16) ayat: 97 dan As-Sajadah (41) ayat: 46

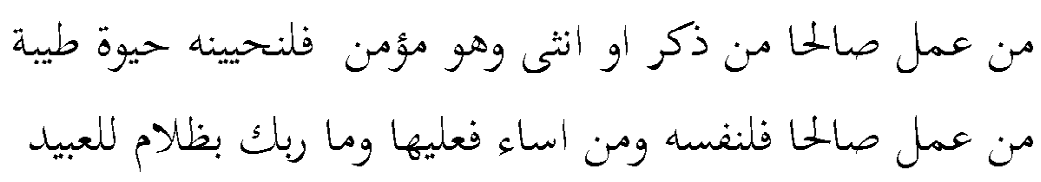

Kedua, meskipun manusia diberi kemungkinan mengetahui kualitas moral dari semua perbuatannya, namun secara prinsip mereka adalah bebas untuk menentukan jalan hidupnya sendiri-sendiri. Tidak ada paksaan untuk mengikuti atau tidak mengikuti pesan-pesan-Nya seperti dalam surat Al-Baqarah (2) ayat 256:

$$
\text { لا لاكراه ف اللدين قل تبين الرشا من الغي... }
$$

Ketiga, Allah swt senantiasa mengamati dan mencatat gerak-gerik tubuh dan hati manusia sekecil-kecilnya, Dia mengetahui apa saja yang disembunyikan dalam hati dan apa yang ditampakkan. Seperti yang termaktub dalam surat al-Mầidah [5] : 61 dan surat al-Zalzalah [99] : 7-8 :

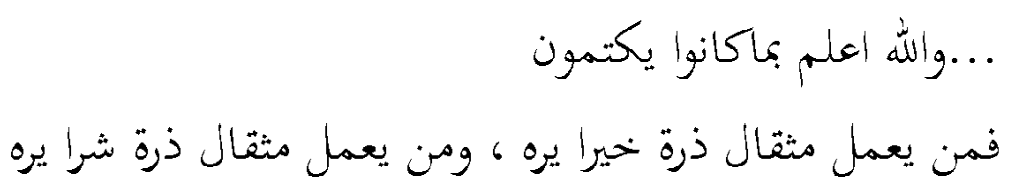

Tiga paradigma diatas, yaitu kemungkinan mengetahui kualitas moral, kebebasan berbuat serta doktrin tentang pencatatan amal, secara bersama-sama merupakan condition sine qua non sekaligus jaminan obyektifitas penilaian Allah. Namun demikian ukuran kemuliaan yang hakiki di hadapan Allah adalah kualitas taqwa dan apabila berbuat keburukan maka keburukan tersebut akan menyebabkan martabatnya menjadi rendah.

Tidak seperti pada kajian-kajian tafsir tradisional yang pada umumnya cenderung membatasi pada sisi pertanggungjawaban yang bersifat ukhrawi dan individual, pada konteks kekinian perlu ditelaah lebih lanjut adalah sisi pertanggungjawaban yang bersifat kolektif duniawi. al-Qur'an hanya menyampaikan pesan-pesan kepada umat manusia sebagai individuindividu mandiri, tetapi juga memberikan bimbingan tentang kehidupan kolektif. Dalam 
ljtihad, Jurnal Wacana Hukum Islam dan Kemanusiaan, Volume 17, №. 1, Juni 2017: 137-154

Islam ada pokok-pokok ajaran tentang etika pergaulan antar manusia, dan dalam hubungan antara manusia dengan lingkungan hidupnya. Mengabaikan ajaran-ajaran moral tersebut akan berakibat tidak hanya penderitaan batin dan siksaan (akhirat) secara individual, tetapi secara kolektif (generasi) mereka juga akan menerima hukuman, sekarang di dunia ini juga (Huda, 1996: 122).

\section{Penutup}

Dari uraian di atas dapat ditarik kesimpulan bahwa kode etik profesi hakim mengandung nilai-nilai moral yang menjadi landasan kepribadian hakim secara professional yaitu: pertama, kebebasan artinya sebagai manusia mempunyai kebebasan baik kemandirian moral maupun keberanian moral yang dibatasi norma-norma yang berlaku. Kedua, keadilan, yaitu memperlakukan sama terhadap manusia dengan memberikan apa yang menjadi haknya. Ketiga, kejujuran yaitu dalam penegakan hukum harus dilandasi sifat kejujuran dalam hati nurani dan kebenaran akal (ratio) dari mulai pemeriksaan perkara, pencarian hukum sampai pada pemutusan perkara secara patut (equity) dengan melihat situasi, apa yang seharusnya diperbuat berdasarkan undang-undang yang mengandung keadilan dan kebenaran di masyarakat. Etika profesi hakim dan hukum adalah merupakan satu kesatuan yang secara inheren terdapat nilai-nilai etika Islam yang landasannya merupakan pemahaman dari alQur'an, sehingga pada dasarnya Kode etik profesi hakim sejalan dengan nilai-nilai dalam sistem etika Islam. Etika hukum Islam dibangun di atas empat nilai dasar yaitu pertama, kebenaran yaitu adanya konsep kebenaran menjadikan manusia percaya untuk berbuat baik karena taat akan hubungan makhluk dan khaliq. kedua, keadilan yaitu adanya penyemarataan (equalizing) dan kesamaan (leveling) hak dalam bidang hukum yang dibangun dengan konsep keadilan mutlak dan sempurna secara transendental antara hukum dan moralitas. Ketiga, kehendak bebas yaitu manusia walaupun dibatasai oleh norma-norma yang ada tetapi mempunyai kehendak bebas/kebebasan (free will). Keempat, pertanggung jawaban yaitu sebagai tuntutan dari kehendak bebas yaitu adanya pertangungjawaban sebagai batasan dari apa yang diperbuat manusia dan harus dipertanggungjawabkan. 


\section{Daftar pustaka}

A. Hanafi. Pengantar Theologi Islam. Jakarta: Pustaka al-Husna, 1992.

A. Mustofa. Akhlak Tasauf. cet. ke-1. Bandung: Pustaka Setia, 1997.

A’la, Abd. Melampani Diaolog Agama. ed. Qamaruddin SF, cet. ke-1. Jakarta: Kompas Media Nusantara, 2002.

Abdullah, M. Amin. Filsafat Etika Islam. Alih bahasa: Hamzah. Cet. ke-1. Bandung: Mizan, 2002.

Al-Asqalani, Al-Hafizh ibn Hajar. Bulügul Mâram, Kitab al-Qada, Hadis nomor 6 Semarang: Toha Putra, t.t. . Bulügul Māram, Kitab al-Qada, Hadiṣ nomor 1 Semarang: Toha Putra, t.t.

Al-Nisaburi, Imām Abī Husain Muslim Bin al-Hajjaj. Al-Jämi' al-Sahih. Juz V. Beirut: Dar alFikr, tt.

Amal, Taufiq Adnan. Metode dan Alternatif Neomodernisme Islam Fąlurrahman. Bandung: Mizan, 1992.

Amin, Ahmad. Etika (Ilmu Akblak). alih bahasa Farid Ma'ruf, cet. ke-8, Jakarta: Bulan Bintang. 1995.

Amril M. Studi Pemikiran Filsafat Moral Raghib Al-Isfahani (w.土1108 M). Disertasi tidak diterbitkan. Yogyakarta: IAIN Sunan Kalijaga, 2001.

Arto, H.A. Mukti. Praktek Perkara Perdata Pada Pengadilan Agama. Cet. ke-3. Yogyakarta: Pustaka Pelajar, 2000.

Ash Sh\{iddiqi, Tengku Muhammad Hasbi. Peradilan Dan Hukum Acara Islam. Cet. ke-1. Semarang: PT Pustaka Rizki Putera, 1997.

Azizy, Qodri. Reformasi Bermazhab: Sebuah Ikbtiar Menuju Ijtibad Sesuai Saintifik-Modern. Cet. ke-1. Jakarta: Teraju, 2003.

Bisri, Cik Hasan. Peradilan Islam Dalam Tatanan Masyarakat Indonesia. Bandung : Rosda Karya, 1997.

Engineer, Asghar Ali. Islam dan Teologi Pembebasan. Alih bahasa: Agung Prihantoro. cet. ke-2. Yogyakarta: Pustaka Pelajar, 2000.

Fakhry, Madjid. Etika Dalam Islam. Alih bahasa: Zakiyuddin Baidhawy. Cet. ke-1 Yogyakarta: Pustaka Pelajar, 1996.

Fauroni, R. Lukman. Etika Bisnis dalam al-Qur'ân. Tesis. Yogyakarta: IAIN Sunan Kalijaga, 2001.

Harahap, M.Yahya. Kedudukan Kewenangan Dan Acara Peradilan Agama. Cet. ke-1. Jakarta: Pustaka Kartini, 1993. 
ljtihad, Jurnal Wacana Hukum Islam dan Kemanusiaan, Volume 17, №. 1, Juni 2017: 137-154

Huda, Miftahul. Dimensi Etis Pesan-pesan al-Qur'an: Sebuah Telaah Filsafat. Tesis. Yogyakarta: IAIN Sunan Kalijaga, 1996.

Izutsu ,Toshihiko. Etika Beragama Dalam Islam. Cet. ke-1. Jakarta: Pustaka Firdaus, 1993.

Manan, B. Perkembangan Metodologi Penelitian Hukum. Jurnal Hukum dan Peradilan, 2012.

Marzuki, P.M. Penelitian Hukum. Jakarta: Kencana Prenada Media Group, 2009.

Mawardi, Imam. Hukum Tata Negara Dan Kepemimpinan Dalam Takaran Islam. Cet. ke-1. Jakarta: Gema Insani Press, 2000.

Muhammad, Abdul Kadir. Hukum Acara Perdata Indonesia. Bandung: Citra Aditya Bakti, 1992.

Muhammad dkk. Visi al-Qur'ân Tentang Etika Dan Bisnis. Cet. ke-1. Jakarta: Salemba Diniyah, 2002.

Muhammad, A.K. Hukum dan Penelitian Hukum. Bandung: PT Citra Aditya Bakti, 2004.

Muslehuddin, Muhammad. Filsaafat Hukum Islam dan pemikiran orientalis Studi Perbandingan. Terjemah: Yudian Wahyudi Asmin. Cet. ke-3. Yogyakarta: Tiara Wacana, 1997.

Nasir, Salihun A. Tinjanan Akblak. Cet. ke-1. Surabaya: al-Ikhlas, 1991.

Nurdin, Muslim. Moral Dan Kognisi Islam. Cet. ke-1. Bandung: Alfa Beta, 1993.

Quasem, M. Abdul. Etika Al-Ghazali Etika Majemuk di dalam Islam. Cet. ke-1. Bandung: Pustaka, 1988.

Rasjid, Sulaiman. Fiqib Islam. Cet. ke-27. Bandung: Sinar Baru Algesindo, 1994.

Sidiktono, dkk. Ibadah dan Akhlak Dalam Islam. Cet. ke-1. Yogyakarta: UII Press, 1998.

Soekanto, S. Penelitian Hukum Normatif Suatu Tinjauan Singkat. Cet. Ke-2. Jakarta: PT. Raja Grafindo Persada, 2009.

Suseno, Frans Magnis. Etika Dasar: Masalah-masalah Pokok Filsafat Moral. Yogyakarta: Kanisius, 1990.

Undang-undang Nomor 4 Tahun 2004 Tentang Kekuasaan Kehakiman.

Undang-undang Nomor 7 Tahun 1989 Tentang Pengadilan Agama. 